\title{
Cinco desenhos de Viorel Pîrligras, apresentado por George Popescu
}

Viorel Pîrligras: o esbanjador de talentos

Viorel Pîrligras é um esbanjador: esbanjador dos dons com os quais foi abençoado, a paixão pela leitura, pelo cinema, pela arte na multiplicidade metamórfica de suas manifestaçóes. Ele oscilou entre a pintura, a que dedicou - do ponto de vista didático - sua infância e adolescência, a ficção científica, com a qual continua a conviver, exteriormente e interiormente, mas sobretudo a história em quadrinhos, área na qual é um protagonista renomado e reconhecido em seu país e no exterior.

Ele também esbanja sorte: possuidor de uma admirável vocação artística, apreciador de obras alheias, de seus próximos, de amigos ou de meros conhecidos, continua a dizer não às tentativas - que não faltam nos meios que frequenta - de expor seus numerosos e incitantes sucessos diante de um público mais amplo, quer se trate de desenhos, de pinturas, ou de fotografia, da qual se tornou recentemente uma vítima voluntária.

O único domínio no qual ele se afirmou como um produtivo protagonista foi o de histórias em quadrinhos: organizador e participante de renomadas exposiçóes nacionais e internacionais (na Bélgica, na França, na Itália, e na Croácia, onde tem muitos amigos e admiradores), recebeu prestigiosos prêmios, sendo o mais importante aquele atribuído a um livro inspirado em uma narrativa de um escritor romeno clássico, I.L Caragiale.

Quando o conheci, nos já distantes anos 1980, ele interpretava, com talento e inteligência artística excepcionais, o papel de um travesti em um espetáculo realizado por um grupo de teatro amador, no qual ele se revelou um jovem ativo, aberto a uma carreira cheia de promessas. Os caprichos e as infidelidades da existência, que eram os vetores do destino na Romênia há um quarto de século, o impulsionaram a ocupaçóes menos espetaculares: desenho técnico em uma empresa de construção, mas sei que certamente, 
mesmo nessas condiçóes, seus trabalhos guardavam um espírito inovador que faz parte de sua estrutura interior.

Viorel Pîrligras nunca teve e não tem mestres atualmente. De certa forma, ele é um autodidata, mesmo que tenha saído de uma excelente escola de arte, a do Liceu Marin Sorescu em Craiova; aprendeu mais sozinho do que com seus professores, a quem sempre apreciou e acompanhou ao longo dos anos em sua postura de jornalista, atento especialmente às tribulaçóes culturais, manifestando desprezo total às futilidades políticas ou as do showbiz. A curiosidade, sinal de uma alma perspicaz, permanentemente alerta, representa, na minha opinião, uma outra dimensão de sua personalidade complexa.

Mas, para além de todos esses dons preciosos de impacto criativo e modelador, Viorel Pîrligras, que destila em seu próprio ser uma vocação extraordinária, a da amizade, possui ainda em seus genes duas outras qualidades raras: a modéstia e a discrição. Ambas mostram, acredito eu, seu modo particular de ser no mundo, de inserir-se entre os próximos e de enriquecê-los com uma amizade cuja gratuidade atinge uma dimensão ontológica.

Seus desenhos, sobretudo os que se inscrevem em uma perspectiva caricatural, exibem uma precisão de linhas de um grande mestre, mantendo, ao mesmo tempo, as volutas de uma ironia que atinge a dimensão do lúdico. No caso de suas fotografias, uma paixão mais recente, mas assumida em nome da criação, elas não parecem - e não são, definitivamente - o resultado de um trabalho técnico, tão utilizado nesta época da multimídia e da efemeridade da arte, incluindo o risco do kitsch, mas sim o ardor de uma espontaneidade e de uma apropriação direta do real insidioso.

Artista completo e autêntico, a Viorel Pîrligras resta apenas ativar seu potencial, atenuando sua modéstia e deixando a discrição para o círculo de amigos, em prol de um engajamento mais audaz dos dons que lhes foram destinados.

Tradução do francês de Jéssica Teixeira Magalhães (Mestranda em Literaturas de Lingua Francesal UFRJ) 


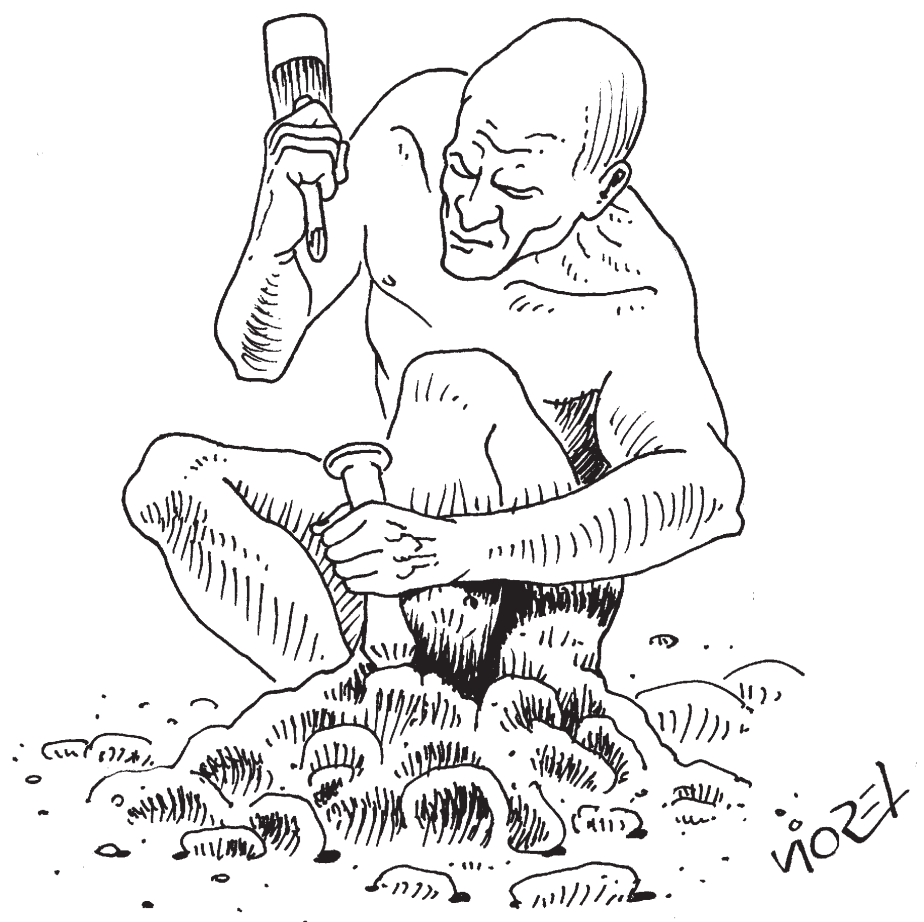




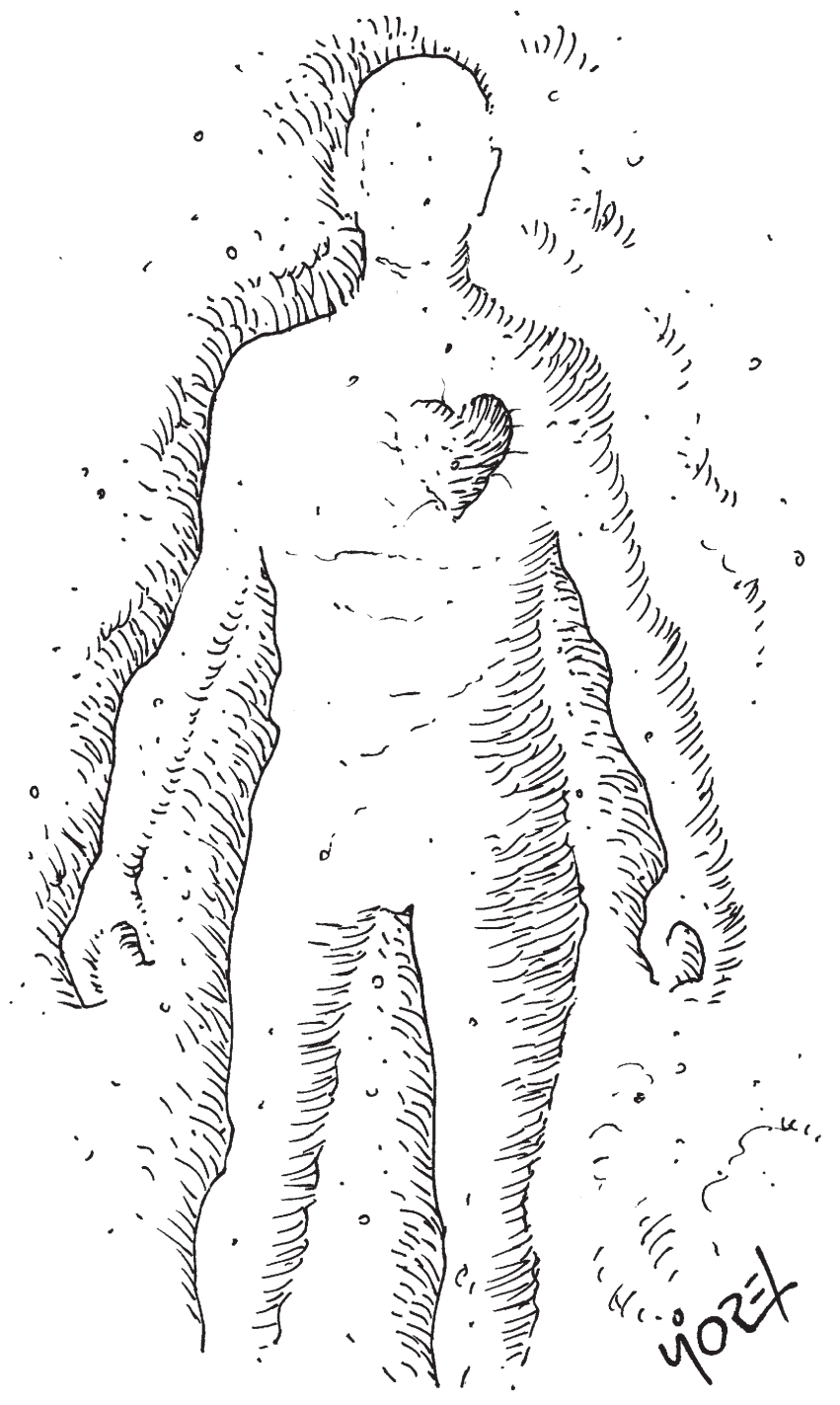




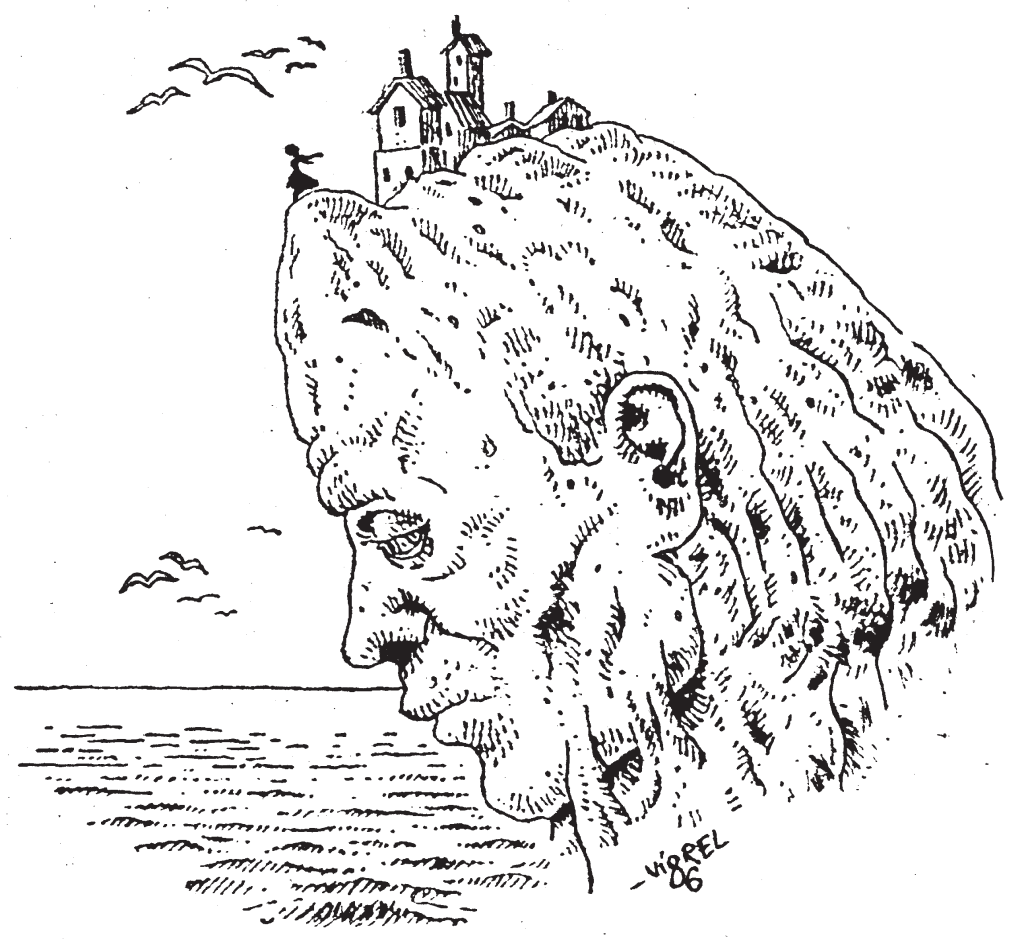




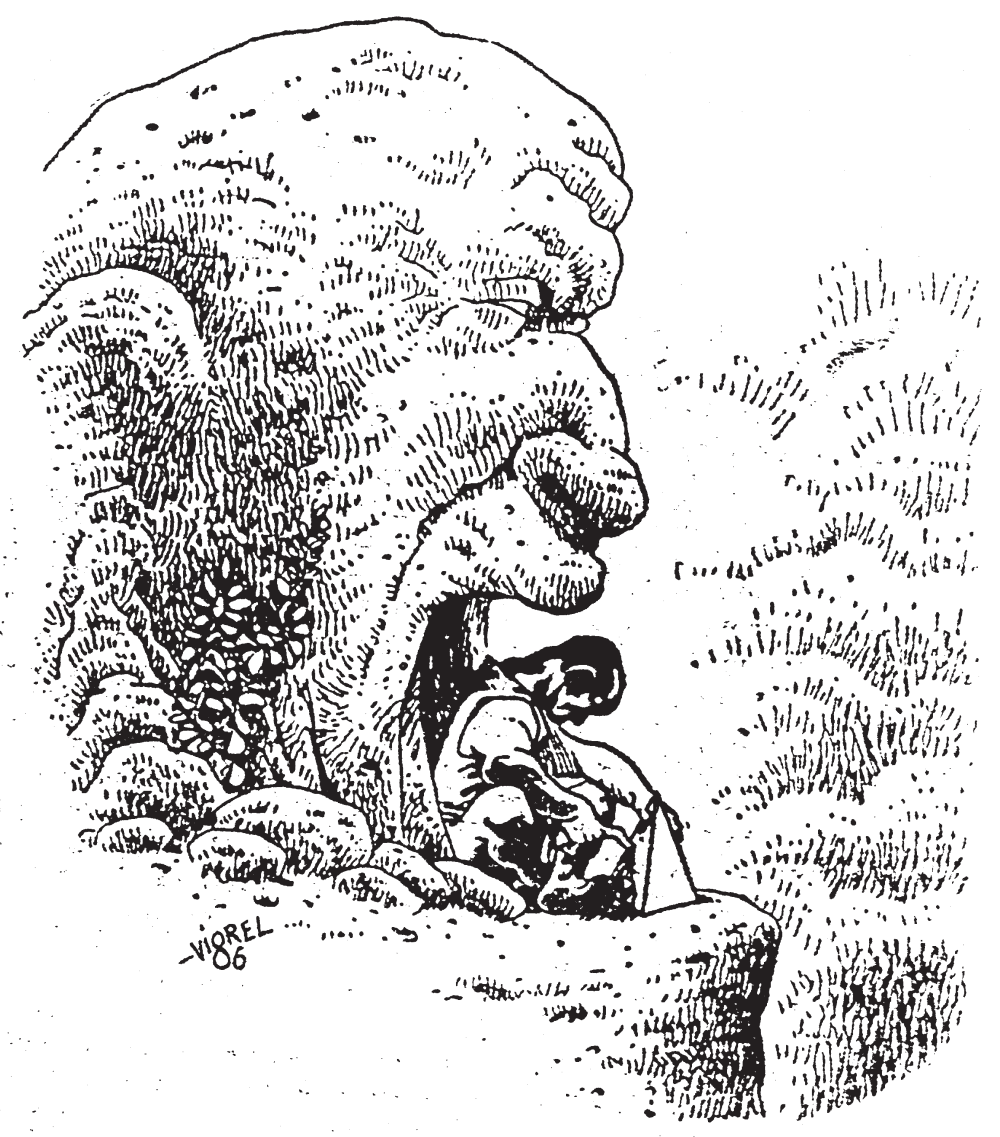




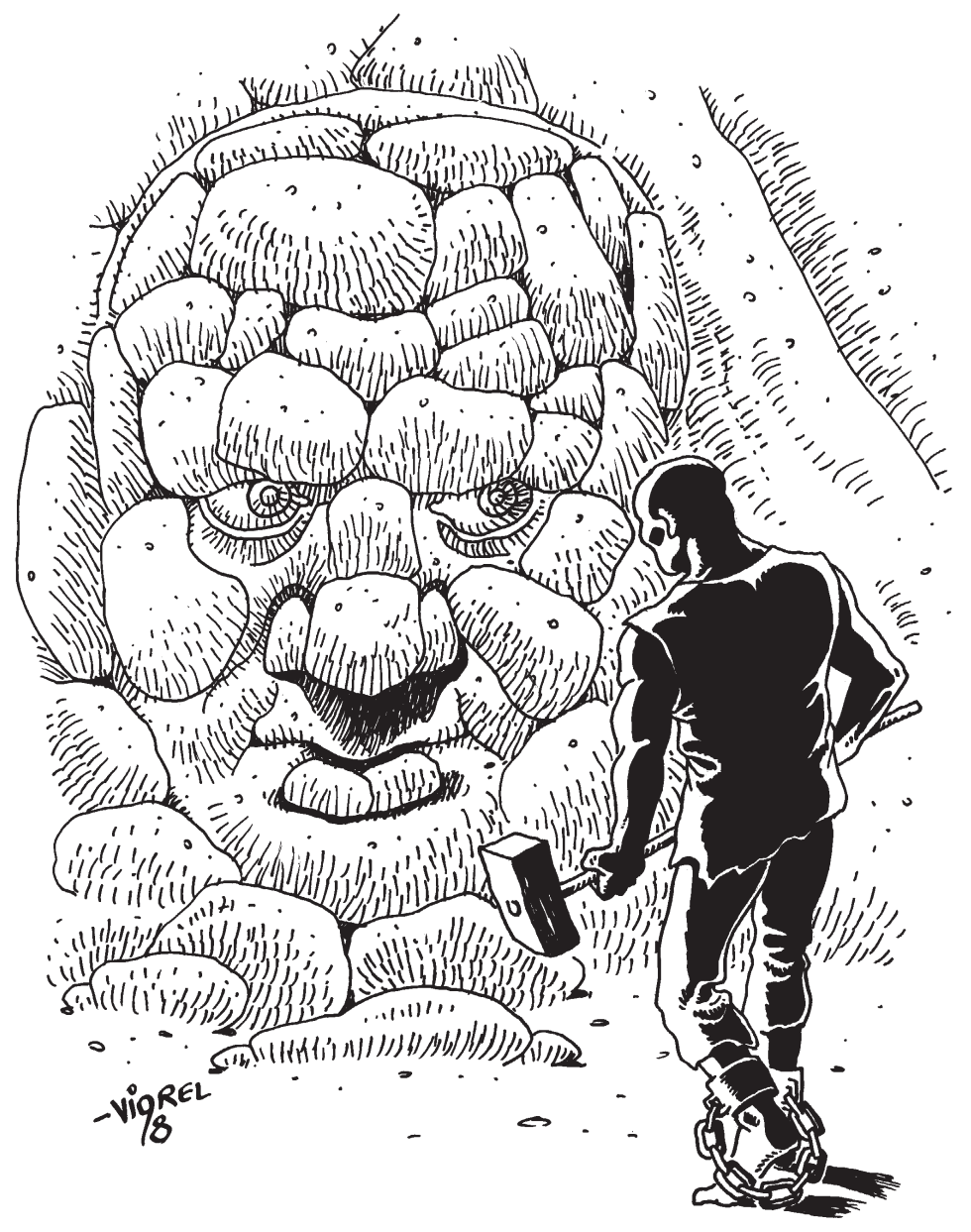

